\title{
National Memory and Digital Modularity. An Attempt to Create a Digital Archive of Science and Culture
}

\author{
Dmitriy B. Sporov* \\ Lomonosov Moscow State University \\ 1 Leninskie Gory, Moscow, 119991, Russia
}

Received 20.02.2016, received in revised form 17.03.2016, accepted 22.04.2016

The article disscusses some questions, which emerged during the work with the Moscow State University's collection of recorded oral memories. What are the possibilities and the challenges which face the online-archivists? Is there a need to create some new type of the chrestomaty - a wikichrestomaty - i.e. a project, constantly updated by every active user? The work with the memoirs shows us that the conceptual constructs which are usually called national memory, places of memory, collective memory etc., are very versatile. Why? We think that the soviet doublethinking which has become civilizational code, has shaped the relationships with the past.

Digital modularity gives the possibility to remember and to create the points of assemblage and to accept the past. Every person we talk with, with all the limitless variability of the subjects and opinions, says that for the past 100 years there weren't any family that didn't confront a catastrophe. That's why in the context of the extreme instability of the common representation of past the stories of people, who achieved some success in creative history of the last century, are very important.

Keywords: oral history, archeography, digital archives, online-archivists, Soviet history, wikichrestomaty, national memory, ideocracy.

DOI: 10.17516/1997-1370-2016-9-7-1615-1617.

Research area: history.

1. The MSU has a relatively small (about 2000 items) collection of recorded oral memories on history of science, culture and everyday life. Established in 1967, this collection, which comprises talks with some well-known personalities of science and culture, e.g. Mikhail Bakhtin, Nikolay Timofeev-Ressovsky, Vyacheslav Ivanov etc., is being updated constantly. Thanks to the personal style of its founder, V.D. Douvakin (1909-1982), all the conversations bear very informal character. Three years ago we launched the Oralhistory.ru site to publish the items from this collection (we started by the more recent talks and now we are about to publish the old ones, recorded between 1960-1990's). We aim to publish all the collection according to the archeography rules and to create a constantly updated archive. We managed to record 500 new conversations, from which 150 were published on the web.

(C) Siberian Federal University. All rights reserved

* Corresponding author E-mail address: sporunet@gmail.com 
2. The publication and systematization of big amount of memoirs bring out the question of the modularity and variability of digital archives. What are the possibilities and the challenges of the online-archivists? The beauty of the oral history in general and our project in particular is we, while respecting the traditions of XX's century historiography, create not a history of state and sovereigns but a history of simple person and, what is important for our society and our subject, the history of liberty, of humanism and of the quest for the meanings. History of science and culture is, obviously, the domain of such a 'new history'. Variability and accessibility of the sources gives the user a possibility to chose and construct his own point of view, because there are different evidences which are updated, and the polycentricity of the past becomes obvious. In other words, the growing volumes of the the sources of historical data on the web produce some new constructs of the national memory or substantially correct the existing ones. Consequently, there has to be a new type of the chrestomaty - a wiki-chrestomaty - i.e. a project, constantly updated by every active user. We started to work in this direction by cooperating with Wikimedia (we are second Wiki-resident in Russia) and by inserting this information into existing Wiki-projects: Wikipedia (integration of our content into articles on Wikipedia), Wikimedia Commons (full videorecording of the conversations), Wikivoices (voice samples).

3. The work with the memoirs shows us that the conceptual constructs which are usually called national memory, places of memory, collective memory etc., are very versatile. Why? We think that the soviet doublethinking which has become civilizational code, has shaped the relationships with the past, too.

The main aspect of the national memory in the USSR was the state policy on creating the 'new man' with 'clear mind'. This task, sometimes achieved, sometimes not, supposed a special set of national memory assemblage points. The points of memory were consolidated in the history of the Communist Party and the victories of the young Republic. The link with the past and the succession were considered obsolete. The memory, including the family memory, was one of the indexes of independence and distance from the cause of the construction of the new socialist society.

After the Perestroyka the national memory was literarily inverted, and the main attention was focused on the previously unknown experience of XX century as opposed to the soviet human canon. The soviet experience of constructing the national memory and the need of creating the new places of memory as a base for the post-soviet nationhood gave the educated class ground to think that there is a possibility and the necessity to create the universal history and the right point of view on it. And it resulted in conscious constructing of the national memory according to the principles of myth. The national memory in Russia is an editorial of the Pravda newspaper.

4. Ideocracy is the specific place of memory of the group we are referencing to. Even though the common cause (the ideology) was fully and secretly rejected, there weren't anything that influenced the life of the soviet intelligentsia more than the totalitarian power. In 2011-2013 we studied how was created the pseudoscientific discipline, which was to be the right base for all aspects of soviet life, called scientific communism (we recorded 58 conversations). The main conclusion of our work is: not only the ordinary people, but the architects of the idology believed that there was a necessity to simulate the socialism and they called the science communism 'a discipline with a limited shell-life'. Such a perception is an interesting evidence of distance and the aspiration towards conformism as evolutionary role model in the context where the common is growing bigger and 
the particular is shrinking which is a characteristic trait of relationship between a man and the power in Russia.

5. Simulative activity, simulative sociality, simulative scientificity could not but request a simulative national memory, whose main task is rigorous mimetism. The places of memory have become so versatile and sometimes antithetical, that it has become easier to construct the national memory according negative identity. The uniqueness of the situation is that even today there is no well rooted constructs of national memory, it is easy to create than to remember. In this context the digital modularity gives the possibility to remember and to create the points of assemblage and to accept the pas. We have to mention that every person we talk with, with all the limitless variability of the subjects and opinions, says that for the past 100 years there weren't any family that confronted a catastrophe. And this is a very important conclusion which cannot even be named. That's why in the context of the extreme instability of the common representation of past the stories of people, who achieved some success in creative history of the last century, are very important.

\title{
Национальная память и цифровая модульность: попытка создания цифрового архива науки и культуры
}

\author{
Д.Б. Споров \\ Московский государственный университет \\ им. М.В. Ломоносова \\ Россия, 119991, Москва, Ленинские горы, 1
}

\begin{abstract}
В статье рассматривается ряд вопросов, возникших во время работы с коллекиией записей словесной памяти Московского государственного университета. С какими возможностями и трудностями сталкиваются онлайн архиваторы? Имеется ли необходимость в создании нового типа хрестоматии - вики-хрестоматии, т.е. проекта, который может обновляться любым активным пользователем? Работа с мемуарами показывает, что понятийные аппараты, как правило называемые национальной памятью, местом памяти, коллективной памятью и т.д., очень изменчивы. Почему? Мы считаем, что советские двойные стандарты, ставшие иивилизачионным кодом, сформировали определенные отношения с прошлым.

Цифровая модульность позволяет хранить в памяти, создавать точки соприкосновения с прошльм и принимать его. Каждый человек, с которым мы говорим, учитывая бесконечное разнообразие обсуждаемых тем и мнений, считает, что за последние 100 лет нет ни одной семьи, которая не столкнулась бы с катастрофой. В этой связи, в контексте крайней нестабильности сегодняшнего представления о прошлом, истории людей, добившихся успеха в творческой истории прошлого века, очень важны.
\end{abstract}

Ключевые слова: иифровые гуманитарные науки, центр цифровых гуманитарных технологий Университетского колледжа Лондона, инновационная кривая.

Научная специальность: 07.00.00 - исторические науки. 